\title{
Porphyrin accumulation induced by 5-aminolaevulinic acid esters in tumour cells growing in vitro and in vivo
}

\section{RG Tunstall', AA Barnett', J Schofield', J Griffiths', DI Vernon', SB Brown' and DJH Roberts*,I}

'Centre for Photobiology and Photodynamic Therapy, University of Leeds, Leeds LS2 9JT, UK

The ability of 5-aminolaevulinic acid and some of its esterified derivatives to induce porphyrin accumulation has been examined in CaNT murine mammary carcinoma cells growing in culture and as tumours in vivo. Topical or intravenous administration of 5-aminolaevulinic acid-esters to mice bearing subcutaneous tumours produced lower porphyrin levels in the tumour than an equimolar dose of 5-aminolaevulinic acid. Reducing the dose of intravenous hexyl- or benzyl-ALA and topical hexyl-5-aminolaevulinic acid resulted in a dose-dependent reduction in porphyrin accumulation. A number of normal tissues accumulated higher concentrations of porphyrins than tumour tissue following intravenous administration of 5-aminolaevulinic acid-esters. Esterase activity in these normal tissues was greater than that in tumour tissue. In contrast to the situation in vivo, all of the 5-aminolaevulinic acid-esters examined were at least as effective as 5-aminolaevulinic acid when applied to cloned CaNT cells in vitro, with the drug concentration required for maximum porphyrin accumulation varying with ester chain-length. Tumour cells growing in culture released esterase activity into the medium. These findings suggest that the efficacy of 5aminolaevulinic esters may vary depending on the esterase activity of the target tissue, and suggest caution when interpreting the findings of in vitro studies using these and similar prodrugs.

British Journal of Cancer (2002) 87, 246 -250. doi: I0.1038/sj.bjc.6600460 www.bjcancer.com

(c) 2002 Cancer Research UK

Keywords: aminolaevulinic; esters; protoporphyrin-IX; photodynamic; PDT

Photodynamic therapy (PDT) is increasingly being used for the treatment of many malignant and pre-malignant conditions. Although the photosensitising drug Photofrin-II ${ }^{\mathbb{R}}$ has received regulatory approval for use in a number of conditions (Dougherty et al, 1998), patients often have to be limited to subdued lighting for several weeks following treatment due to its prolonged retention in the skin (Carruth, 1998). In contrast, skin photosensitivity following the systemic administration of 5-aminolaevulinic acid (ALA), a metabolic precursor of the photosensitiser protoporphyrin-IX (PpIX), is relatively mild and short-lived (Rick et al, 1997). ALA-based PDT is now being investigated as a treatment for several conditions (Roberts and Cairnduff, 1995; Peng et al, 1997b).

The hydrophilic nature of ALA (Novo Rodriguez et al, 1995) may limit its ability to penetrate through skin or cell membranes (Peng et al, 1997a) and thereby restrict its topical use to the treatment of superficial disease. As a result, esterified derivatives of ALA, which are less hydrophilic than the parent compound (Uehlinger et al, 2000), are under investigation as possible alternatives to ALA. Work in vitro has demonstrated that a number of cell lines have the ability to take-up and metabolise certain ALA-esters into PpIX at a faster rate, and at lower concentrations, than ALA (Kloek and Beijersbergen van Henegouwen, 1996; Peng et al, 1996). A number of in vivo studies have suggested that topical application of some ALA esters can result in greater PpIX accumulation than similar concentrations of ALA (Peng et al, 1996; Lange et al, 1999; van den Akker et al, 2000). In contrast, however, clin-

*Correspondence: DJH Roberts, The School of Biomedical Sciences University of Leeds, Leeds LS2 9JT, UK; E-mail: d.j.h.roberts@leeds.ac.uk Received I4 February 2002; revised 7 May 2002; accepted 10 May 2002 ical work with human solar keratoses showed methyl-ALA to induce less PpIX than ALA (Fritsch et al, 1998).

ALA has been shown to be effective at inducing PpIX after oral, intravenous (i.v.) or topical application in vivo (Cairnduff et al, 1995; Peng et al, 1995; van den Boogert et al, 1998). As yet, no data regarding the systemic administration of ALA-esters have been published. The aim of this study was to investigate the induction of porphyrins by ALA and ALA-esters in mouse mammary carcinoma cells growing both in vitro and as tumours in vivo.

\section{MATERIALS AND METHODS}

\section{Chemicals}

ALA hydrochloride was synthesised using a method based on that of Pfaltz and Anwar (1984), purified with active charcoal and recrystallised from acetone. Hydrochloride salts of ethyl-, propyl-, butyl-, pentyl-, cyclohexyl-, hexyl- and benzyl-ALA were prepared using the method described by Kloek et al (1998). Elemental analysis showed them to be at least $90 \%$ pure. Unguentum Merck $^{\mathbb{R}}$ emollient cream was obtained from Merck Ltd, Lutterworth, UK. All other chemicals were obtained from BDH Laboratory Supplies, Poole, UK and Sigma-Aldrich Co. Ltd., Poole, UK.

\section{Tumour and animals}

The CaNT tumour is a poorly-differentiated non-immunogenic carcinoma, probably of mammary origin, which arose spontaneously in a female CBA/Gy mouse (Hewitt et al, 1973). Tumour and initial breeding pairs of CBA/Gy mice were kindly provided by Dr DJ Chaplin and Mr P Russell respectively (CRC Gray Laboratories, Middlesex, UK). Mice were housed in a $12 \mathrm{~h}$ light/dark cycle 
and given free access to water and food (B\&K Ltd, Hull, UK, Universal Standard Rodent Diet). Once ALA or ALA-ester had been administered, animals were maintained in subdued lighting. All work was carried out in accordance with the UKCCCR guidelines for use of animals in experimental neoplasia (UKCCCR 1998).

Tumours were maintained by serial transplantation for a maximum of 10 passages. For experiments, tumour fragments of approximately $5 \mathrm{~mm}^{3}$ were implanted subcutaneously (s.c.) into the flanks of 6-10-week-old mice $(21-27 \mathrm{~g})$, and allowed to grow to $150-250 \mathrm{~mm}^{3}$ prior to randomisation to control or treatment groups.

\section{Cells and cell culture}

CaNT cells were harvested from tumour explants growing at $37^{\circ} \mathrm{C}$ in Dulbecco's minimal essential medium (DMEM) containing 10\% foetal calf serum (Life Technologies, Paisley, UK) in an atmosphere of $5 \% \mathrm{CO}_{2}$ in air. Clones were prepared by dilution and subsequently shown to be tumorigenic by s.c. inoculation into CBA/ Gy mice. Cells were routinely passaged using 1\% trypsin/EDTA (Life Technologies, Paisley, UK).

\section{ALA and ALA-ester-induced generation of porphyrins in murine tissues}

ALA $\quad\left(0.06-1.2 \mathrm{mmol} \mathrm{kg}^{-1}\right)$ and ALA esters (0.0012$1.2 \mathrm{mmol} \mathrm{kg}^{-1}$ ) in $10 \mathrm{mM}$ phosphate buffered saline (PBS, $\mathrm{pH}$ 7.4) were administered via a lateral tail vein. Animals were killed at intervals up to $24 \mathrm{~h}$ later, and tissue samples $(0.1-0.2 \mathrm{~g}$ wet weight) snap-frozen in liquid nitrogen and stored at $-85^{\circ} \mathrm{C}$.

For topical application, ALA $(20 \% \mathrm{w} / \mathrm{w})$ and hexyl-ALA $(0.02-$ $20 \% \mathrm{w} / \mathrm{w})$ were prepared in Unguentum Merck ${ }^{\mathbb{R}}$ emollient cream immediately prior to use. Skin overlying the tumour was shaved and tape-stripped and $0.2 \mathrm{ml}$ cream rubbed into the skin for two minutes with a gloved finger. Control animals received $0.2 \mathrm{ml}$ cream alone. Tumour tissue was collected $1-6 \mathrm{~h}$ later as described above.

Porphyrin concentrations were determined by a method modified from that of Longas and Poh-Fitzpatrick (1980). The porphyrin extraction efficiency of this assay has previously been calculated as 90\% (Poh-Fitzpatrick and DeLeo, 1977). Briefly, tissue samples were incubated in $1 \mathrm{M}$ aqueous $\mathrm{NaOH}$ in the dark at $40^{\circ} \mathrm{C}$ for $16 \mathrm{~h}$ and porphyrins extracted into $4: 1$ ethyl acetate: acetic acid. The organic layer was removed and porphyrins extracted into $1 \mathrm{M}$ aqueous $\mathrm{HCl}$. Porphyrin fluorescence in the resultant aqueous layer was measured with a Kontron SFM25 fluorimeter (Kontron Instruments Ltd, Watford, UK; excitation 403 nm, emission $602 \mathrm{~nm}$ ). A solution of haematoporphyrin was used as fluorescence standard. Data from tissues treated with ALA- or ALA-ester were corrected by subtracting the porphyrin concentration in equivalent untreated tissues.

\section{ALA and ALA-ester-induced generation of porphyrins in cultured cells}

Cloned CaNT cells were grown in 24-well plates until 50-75\% confluent. After thorough washing in warm PBS, cells were incubated in the dark for $3 \mathrm{~h}$ with ALA or ALA-esters in serum-free DMEM at pH7.4. Cells were then washed twice in PBS and solubilised in the dark in $0.5 \mathrm{ml}$ of $26.5 \mathrm{M}$ formic acid for $15 \mathrm{~min}$ at room temperature. Porphyrin fluorescence was determined as described above. Cellular protein concentration was determined in duplicate wells using the BioRad protein microassay (Biorad Laboratories Ltd, Hemel Hempstead, UK). Porphyrin analyses were performed in quadruplicate, and all experiments were repeated at least twice. Data from cells treated with ALA- or ALA-ester were corrected by subtracting the porphyrin concentration in equivalent untreated cells.

\section{HPLC analysis of porphyrins}

Porphyrins in tissue samples or cultured cells were extracted as described for fluorimetry and the $\mathrm{pH}$ adjusted to 5 or above with saturated sodium acetate. The samples were then further extracted into ethyl acetate, washed with an equal volume of distilled water and passed through a filter paper saturated in ethyl acetate. They were then dried under a stream of nitrogen gas and stored in the dark at $4^{\circ} \mathrm{C}$ until required.

Dry porphyrin samples were dissolved in $100 \mu$ l of methanol containing $10 \% \mathrm{HCl}$ immediately before HPLC analysis. Reverse phase HPLC analysis of $20 \mu \mathrm{l}$ of reconstituted sample was performed using a Waters Nova Pak C18 analytical column $(150 \mathrm{~mm} \times 3.9 \mathrm{~mm})$. Solvent A was $10 \%$ acetonitrile $/ 90 \%$ ammonium acetate $(1 \mathrm{M}, \mathrm{pH} 5.16)$. Solvent $\mathrm{B}$ was $90 \%$ methanol/10\% acetonitrile. Fluorescence detection was performed at $400 \mathrm{~nm}$ excitation and $620 \mathrm{~nm}$ emission. Sample absorbance was measured at $400 \mathrm{~nm}$. Standards solutions of known porphyrins were used to identify the porphyrins in samples.

\section{Non-specific esterase assay}

Non-specific esterase activities in tissue homogenates, lysates of cultured cells and in cell-conditioned or fresh culture medium were determined using an adaptation of the fluorescein diacetate method described by Washbrook and Riley (1997).

\section{Statistical analysis}

Statistical analyses were performed using SPSS v9.0 for Windows. The independent-samples Student $t$-test was used to test the difference between means. Normality of data was confirmed using the Kolmogorov-Smirnov statistic or Q-Q normal probability plot.

\section{RESULTS}

\section{ALA and ALA-ester-induced generation of porphyrins in murine tissues}

Porphyrin levels in the CaNT tumour were highest $1 \mathrm{~h}$ after i.v. administration of ALA or ALA-esters $\left(0.12 \mathrm{mmol} \mathrm{kg}^{-1}\right)$, except in the cases of propyl- and cyclohexyl-ALA which did not induce porphyrin accumulation in tumour tissue (Figure 1). ALA induced higher porphyrin levels than any of its esters $(P<0.001)$.

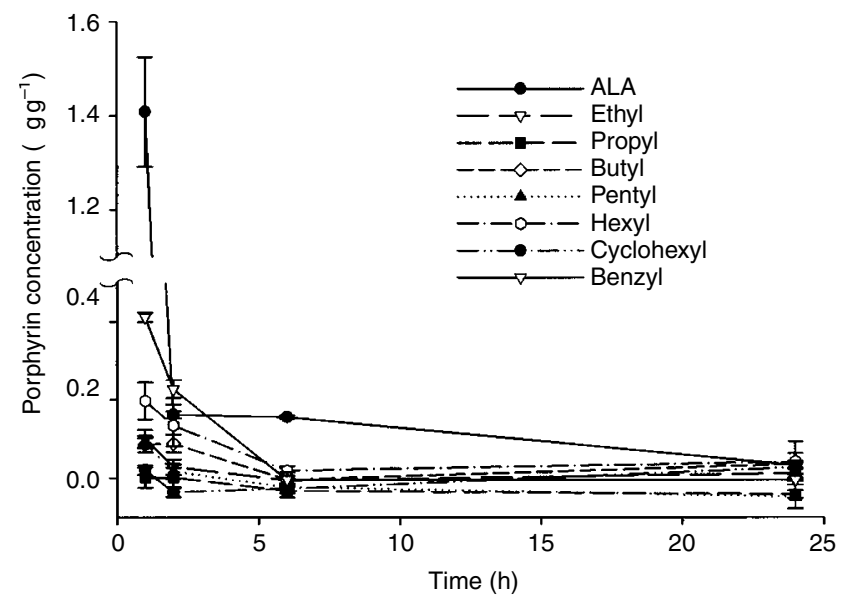

Figure I Porphyrin concentration in s.c. CaNT tumours following i.v. administration of $0.12 \mathrm{mmol} \mathrm{kg}^{-1}$ ALA or its esterified derivatives. Data are means \pm s.e. $(n=4)$. 
Reducing the dose of i.v. administered ALA, hexyl-ALA or benzylALA resulted in a dose-dependent reduction in the concentration of porphyrins accumulating in the tumour (Table 1).

In normal murine tissues, the ability of i.v. ALA and its esters $\left(0.12 \mathrm{mmol} \mathrm{kg} \mathrm{kg}^{-1}\right)$ to induce porphyrin accumulation was tissuedependent (Figure 2). In skeletal muscle, porphyrin levels were generally low, although benzyl-ALA was most effective. In skin and liver, ALA generated the highest porphyrin levels, whereas in the ileum, ALA, butyl-ALA and benzyl-ALA were similarly effective. In the kidney, benzyl-ALA and ALA generated similar porphyrin levels $(0.12>P>0.05)$. As in the tumour, propyl-ALA failed to induce porphyrin accumulation in any of the normal tissues examined.

Topical application of $20 \%$ ALA cream induced porphyrin accumulation in the CaNT tumour, peaking $4 \mathrm{~h}$ after administration (Figure 3). In contrast, $0.02-20 \%$ hexyl-ALA induced little or no porphyrin accumulation in tumour tissue.

\section{ALA and ALA-ester-induced generation of porphyrins in cultured cells}

All ALA-esters induced intracellular accumulation of porphyrins in tumour cell clones (Figure 4a,b). When esters were administered at their optimum concentrations, the resulting porphyrin levels were similar to or above that induced by the optimum concentration of ALA. When pentyl-, hexyl- and benzyl-ALA were administered above concentrations of $6 \mathrm{mM}, 1 \mathrm{mM}$ and $10 \mathrm{~mm}$ respectively, cells became rounded and detached from the substratum. This was not seen for any other ALA-esters at the concentrations investigated.

\section{HPLC analysis of porphyrins induced by ALA and ALA- esters}

Following i.v. administration of ALA at $0.12 \mathrm{mmol} \mathrm{kg}^{-1}$, PpIX accounted for an average of $88 \%$ of the porphyrins in tumour tissue, $98 \%$ in skin, $97 \%$ in skeletal muscle, $80 \%$ in liver, $87 \%$ in ileum, and $89 \%$ in kidney. Following in vivo administration of ALA-esters at $0.12 \mathrm{mmol} \mathrm{kg}{ }^{-1}$, PpIX accounted for $83-100 \%$ of the porphyrins generated by murine ileum depending on the ester applied. When ALA or ALA-esters were used at their optimum concentrations in vitro, PpIX accounted for $94-100 \%$ of porphyrins generated.

\section{Esterase activity in murine tissues and cultured cells}

Non-specific esterase activity varied between the different tissues examined (Table 2). In most cases, tissues with greater esterase activity accumulated a higher concentration of porphyrin following i.v. ester administration.

The mean esterase activity in cultured CaNT cells was $3.0 \pm 0.02$ arbitary units/ $\mu \mathrm{g}$ protein/s. In addition, serum-free DMEM exposed to cells for $3 \mathrm{~h}$ exhibited a mean esterase activity of $946 \pm 7.7$ a.u./ml/s (value corrected for background activity in the medium of $59 \pm 16$ a.u. $/ \mathrm{ml} / \mathrm{s})$.

Table I Porphyrin concentration in s.c. CaNT tumour tissue I h after i.V. administration of ALA, hexyl- or benzyl-ALA. $n=3$ in all cases.

\begin{tabular}{lccc}
\hline & \multicolumn{3}{c}{ Mean porphyrin concentration \pm s.e. $\left(\mu \mathbf{g ~ g}^{-1}\right)$} \\
\cline { 2 - 4 } $\begin{array}{l}\text { Drug dose } \\
\left(\mathbf{m m o l ~ k g} \mathbf{~}^{-\mathbf{1}}\right)\end{array}$ & ALA & Hexyl & Benzyl \\
\hline 0.0012 & - & $0.06 \pm 0.003$ & $0.06 \pm 0.011$ \\
0.006 & - & $0.07 \pm 0.009$ & $0.10 \pm 0.006$ \\
0.012 & - & $0.11 \pm 0.013$ & $0.05 \pm 0.003$ \\
0.06 & $0.39 \pm 0.036$ & $0.21 \pm 0.024$ & $0.09 \pm 0.008$ \\
0.12 & $1.54 \pm 0.12$ & $0.33 \pm 0.047$ & $0.55 \pm 0.012$ \\
\hline
\end{tabular}

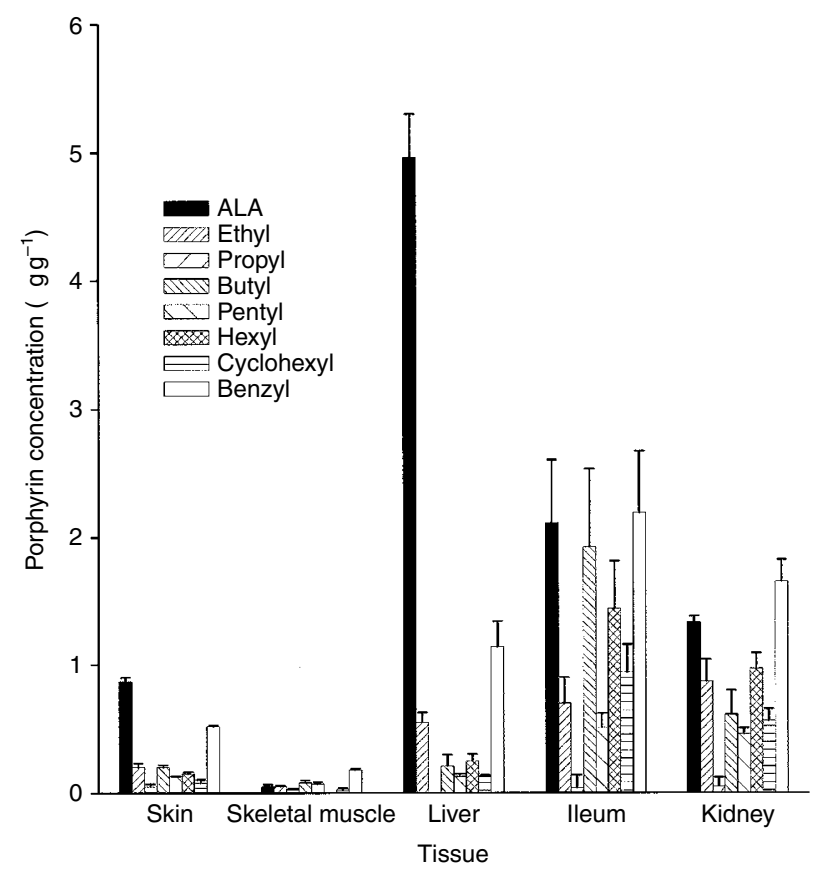

Figure 2 Porphyrin concentration in selected normal mouse tissues Ih after i.v. administration of $0.12 \mathrm{mmol} \mathrm{kg}^{-1}$ ALA or its esterified derivatives. Data are means \pm s.e. $(n=4)$.

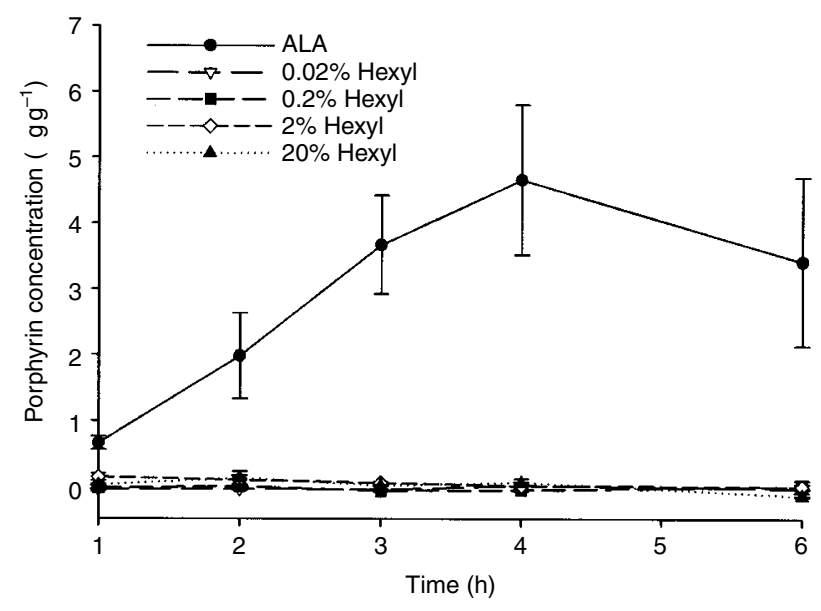

Figure 3 Porphyrin concentration in s.c. CaNT tumours following topica application of emollient cream containing ALA (20\% w/w) or hexyl-ALA $(0.02-20 \%$ w/w). Data are means \pm s.e. $(n=4)$.

\section{DISCUSSION}

I.v. administration of ALA caused the accumulation of porphyrins in CaNT tumour growing s.c. and in a variety of normal murine tissues (Figures 1 and 2). Similarly, topical application of ALA to the skin induced porphyrin accumulation in underlying tumour (Figure 3). These results are in agreement with those of similar previous studies (Cairnduff et al, 1995; de Bruijn et al, 1999). In all cases, the predominant porphyrin species formed was protoporphyrin-IX.

In contrast, i.v. or topical administration of a range of ALAesters had relatively little or no effect on the porphyrin concentration in the s.c. CaNT tumour. However, when given i.v., all the ALA-esters examined, with the exception of propyl-ALA, were able to induce porphyrin accumulation in a variety of normal tissues (Figure 2). This suggests that at least some murine tissues have 
the capacity to utilise certain ALA-esters for porphyrin synthesis, and that the results obtained in tumour tissue are not a reflection of murine metabolism per se.

Previous work in vitro has suggested that a number of ALAesters, including hexyl-ALA, are most effective when used at much lower doses than ALA (Kloek et al, 1998; Lange et al, 1999; Uehlinger et al, 2000). Here, we found that reducing the dose of i.v. hexyl- or benzyl-ALA resulted in a dose-dependent reduction in tumour porphyrin levels to that of untreated controls. Reducing the dose of topical hexyl-ALA had no consistent effect on the very low levels of porphyrins observed in tumours up to $6 \mathrm{~h}$ after appli-
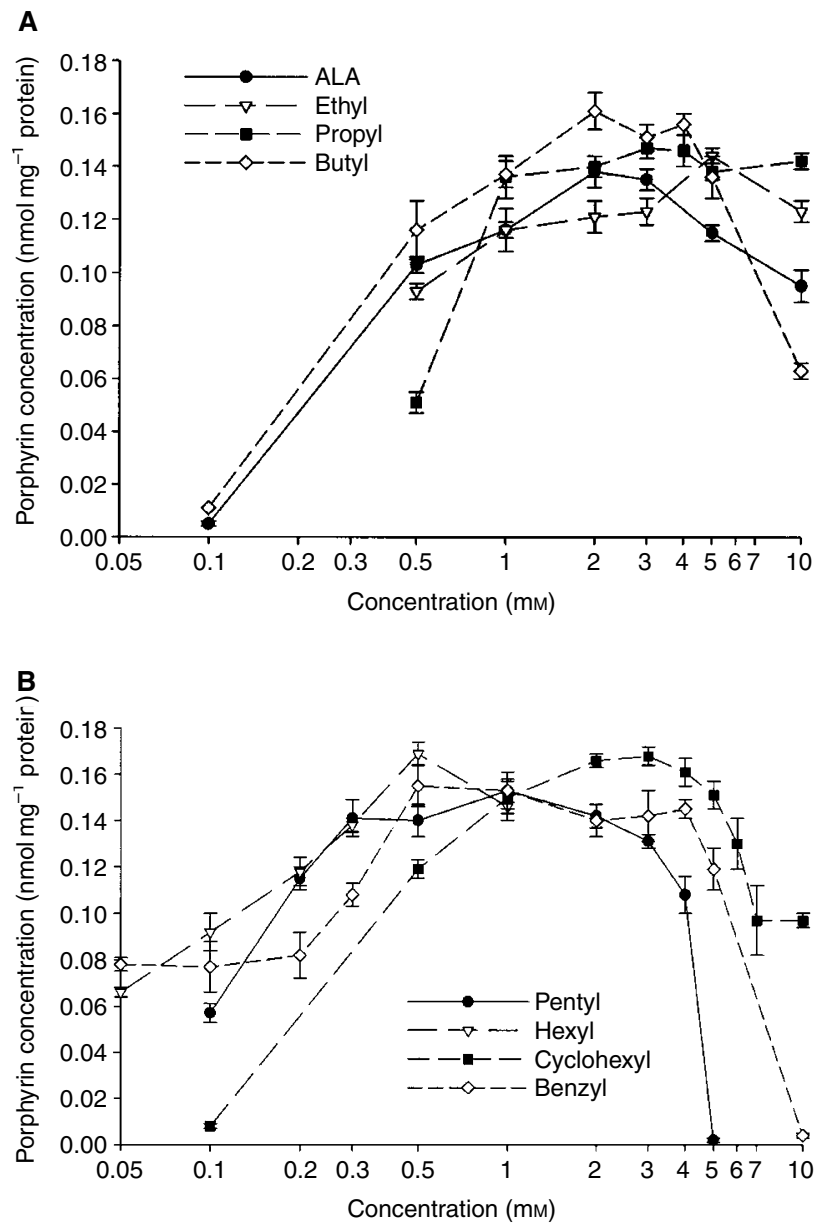

Figure 4 Porphyrin concentration in cultured CaNT cells after $3 \mathrm{~h}$ incubation in serum-free medium containing ALA or (A) elthyl-, propyl- or butyl-ester (B) pentyl-, hexyl-, cyclohexyl- or benzyl-ester. Data are means \pm s.e. $(n=8)$ cation. These findings strongly suggest that the relative inability of ALA-esters to induce porphyrin accumulation in tumour tissue compared to ALA was not the result of the esters being applied at inappropriately high concentrations.

In contrast to the results with CaNT tumours, all ALA-esters examined were able to induce similar or greater porphyrin concentrations than ALA in CaNT cells growing in vitro (Figure 4a,b). The optimum concentration of each ALA-ester was related to the length of the ester-linked chain, with longer-chain compounds inducing maximum porphyrin levels at lower concentrations than the shorter-chain derivatives. These findings are in broad agreement with previous observations (Gaullier et al, 1997; Kloek et al, 1998; Uehlinger et al, 2000).

It is not clear why the ability of ALA-esters to induce porphyrin accumulation differed between CaNT cells in culture and those growing as tumours in vivo. The observation that some non-fatty normal murine tissues were able to utilise at least some of the ALA-esters, including those with the longest carbon chains, suggests reduced bioavailability via sequestration into lipid-rich tissues is unlikely to explain the lack of effect in tumour tissue.

An alternative explanation is that introducing the tumour cells to tissue culture modified their metabolism such that ALA-esters could be more readily utilised. Up-regulation of intracellular non-specific esterase activity could, for example, facilitate ester hydrolysis and hence utilisation in porphyrin biosynthesis. With the exception of liver, there was a tendency for tissues with higher esterase activity to accumulate higher porphyrin concentrations following i.v. ALA-ester administration (Table 2). Although esterase activity in the cultured CaNT cells was relatively low, such cells released esterase activity into the surrounding medium. It is possible that pre-processing of ALA-esters whilst still in the extra-cellular milieu could have made ALA available to the cells in vitro in a way that may not have been available in vivo. Uptake of ALA-ester destined for intra-cellular cleavage at the same time as ALA derived from extra-cellular cleavage, may have resulted in greater ALA availability for porphyrin biosynthesis than could have been achieved by ALA-ester uptake alone. There is some evidence that ALA and at least some ALA-esters are taken into cells via different routes (Rud et al, 2000; Gederaas et al, 2001).

Clinical and animal studies do not yet provide a consistent answer with regard to the efficacy of ALA-esters (Peng et al, 1996; Lange et al, 1999; Fritsch et al, 1998; van den Akker et al, 2000). Here, we have found that several esters are less effective than ALA at inducing porphyrin accumulation in a s.c. mouse tumour. It is possible that the ability of ALA-esters to induce PpIX accumulation may be dependent on factors such as tumour type, metabolic status, or location, as well as on the actual ester applied. This may have significant implications for the clinical usefulness of this group of compounds. Whether the level of esterase activity present in the CaNT tumour is representative of that in other tumours, and whether other tumours would display the same differential response to ALA-esters applied in vitro and in vivo, remains to be determined however.

Table 2 Porphyrin concentration in mouse tissues I h after i.v. administration of ALA or its esterified derivatives $\left(0.12 \mathrm{mmol} \mathrm{kg}^{-1}\right) . \mathrm{n}=4$ in all cases.

Mean porphyrin concentration \pm s.e. $\left(\mu \mathbf{g ~ g}^{-1}\right)$

\begin{tabular}{|c|c|c|c|c|c|c|c|c|c|}
\hline Tissue & $\begin{array}{c}\text { Mean esterase } \\
\text { activity } \pm \text { s.e. } \\
\text { (a.u. } \mu \mathbf{g}^{-1} \text { protein } \mathbf{s}^{-1} \text { ) }\end{array}$ & ALA & Ethyl & Propyl & Butyl & Pentyl & Hexyl & Cyclohexyl & Benzyl \\
\hline lleum & $692 \pm 3.82$ & $2.11 \pm 0.49$ & $0.70 \pm 0.20$ & $0.04 \pm 0.1$ & $1.92 \pm 0.61$ & $0.51 \pm 0.11$ & $1.44 \pm 0.37$ & $0.94 \pm 0.22$ & $2.19 \pm 0.48$ \\
\hline Kidney & $74 \pm 0.45$ & $1.33 \pm 0.05$ & $0.87 \pm 0.17$ & $0.05 \pm 0.07$ & $0.61 \pm 0.19$ & $0.46 \pm 0.05$ & $0.97 \pm 0.12$ & $0.56 \pm 0.10$ & $1.65 \pm 0.17$ \\
\hline Skin & $52 \pm 0.25$ & $0.87 \pm 0.03$ & $0.20 \pm 0.03$ & $0.05 \pm 0.02$ & $0.20 \pm 0.02$ & $0.13 \pm 0.002$ & $0.15 \pm 0.01$ & $0.08 \pm 0.03$ & $0.52 \pm 0.01$ \\
\hline Tumour & $11 \pm 0.07$ & $1.41 \pm 0.12$ & $0.10 \pm 0.02$ & $0.002 \pm 0.03$ & $0.09 \pm 0.02$ & $0.09 \pm 0.01$ & $0.20 \pm 0.05$ & $0.02 \pm 0.01$ & $0.41 \pm 0.01$ \\
\hline Muscle & $0.6 \pm 0.04$ & $0.05 \pm 0.01$ & $0.05 \pm 0.01$ & $0.03 \pm 0.004$ & $0.08 \pm 0.02$ & $0.07 \pm 0.02$ & $-0.03 \pm 0.01$ & $0.03 \pm 0.01$ & $0.18 \pm 0.01$ \\
\hline
\end{tabular}


In conclusion, we have found that a number of ALA esters are at least as effective as ALA at inducing protoporphyrin IX accumulation in murine mammary carcinoma cells in vitro, but that the same compounds are either ineffective, or much less effective than ALA when administered in vivo. The greater complexity of the in vivo environment and/or culture-induced changes in cell properties may have been responsible for these differences. Such factors can limit the ability of in vitro test systems to predict drug effectiveness in vivo.

\section{REFERENCES}

Cairnduff F, Roberts DJ, Dixon B, Brown SB (1995) Response of a rodent fibrosarcoma to photodynamic therapy using 5- aminolaevulinic acid or polyhaematoporphyrin. Int J Radiat Biol 67: 93-99

Carruth JA (1998) Clinical applications of photodynamic therapy. Int J Clin Pract 52: 39-42

de Bruijn HS, van d, V, Robinson DJ, Star WM (1999) Improvement of systemic 5-aminolevulinic acid-based photodynamic therapy in vivo using light fractionation with a 75-minute interval. Cancer Res 59: $901-904$

Dougherty TJ, Gomer CJ, Henderson BW, Jori G, Kessel D, Korbelik M, Moan J, Peng Q (1998) Photodynamic therapy. J Natl Cancer Inst 90: $889-905$

Fritsch C, Homey B, Stahl W, Lehmann P, Ruzicka T, Sies H (1998) Preferential relative porphyrin enrichment in solar keratoses upon topical application of delta-aminolevulinic acid methylester. Photochem Photobiol 68: $218-221$

Gaullier JM, Berg K, Peng Q, Anholt H, Selbo PK, Ma LW, Moan J (1997) Use of 5-aminolevulinic acid esters to improve photodynamic therapy on cells in culture. Cancer Res 57: 1481-1486

Gederaas OA, Holroyd A, Brown SB, Vernon D, Berg K (2001) 5-aminolaevulinic acid methyl ester transport on amino acid carriers in a human colon adenocarcinoma cell line. Photochem Photobiol 73: 164-169

Hewitt HB, Blake E, Parter EH (1973) The Effect of Lethally Irradiated Cells in the Transplantability of Murine Tumours. Br I Cancer 77: 123-135

Kloek J, Akkermans W, Beijersbergen van Henegouwen GM (1998) Derivatives of 5-aminolevulinic acid for photodynamic therapy: enzymatic conversion into protoporphyrin. Photochem Photobiol 67: 150-154

Kloek J, Beijersbergen van Henegouwen GM (1996) Prodrugs of 5-aminolevulinic acid for photodynamic therapy. Photochem Photobiol 64: 994-1000

Lange N, Jichlinski P, Zellweger M, Forrer M, Marti A, Guillou L, Kucera P, Wagnieres G, van Den BH (1999) Photodetection of early human bladder cancer based on the fluorescence of 5-aminolaevulinic acid hexylesterinduced protoporphyrin IX: a pilot study. Br J Cancer 80: 185-193

Longas MO, Poh-Fitzpatrick MB (1980) High-pressure liquid chromatography of plasma free acid porphyrins. Anal Biochem 104: 268-276

Novo Rodriguez M, Huttmann G, Diddens H (1995) Chemical Instability of 5-Aminolaevulinic Acid (ALA) in Aqueous Solutions. Proc SPIE 2371: 204-209

Peng Q, Berg K, Moan J, Kongshaug M, Nesland JM (1997a) 5-Aminolevulinic acid-based photodynamic therapy: principles and experimental research. Photochem Photobiol 65: 235-251

Peng Q, Moan J, Warloe T, Iani V, Steen HB, Bjorseth A, Nesland JM (1996) Build-up of esterified aminolevulinic-acid-derivative-induced porphyrin fluorescence in normal mouse skin. J Photochem Photobiol B 34: 95-96

\section{ACKNOWLEDGEMENTS}

This work was supported by Yorkshire Cancer Research, UK. We also wish to thank Amanda Foley for her valuable technical assistance with the HPLC analysis, and the EPSRC National Mass Spectrometry Service Centre, Swansea, for provision of mass spectrometry services.
Peng Q, Warloe T, Berg K, Moan J, Kongshaug M, Giercksky KE, Nesland JM (1997b) 5-Aminolevulinic acid-based photodynamic therapy. Clinical research and future challenges. Cancer 15: $2282-2308$

Peng Q, Warloe T, Moan J, Heyerdahl H, Steen HB, Nesland JM, Giercksky KE (1995) Distribution of 5-aminolevulinic acid-induced porphyrins in noduloulcerative basal cell carcinoma. Photochem Photobiol 62: 906-913

Pfaltz A, Anwar S (1984) Synthesis of a-Aminoketones via Selective Reduction of Acyl Cyanides. Tetrahedron Letters 25: 2977-2980

Poh-Fitzpatrick MB, DeLeo VA (1977) Rates of plasma porphyrin disappearance in fluorescent vs. red incandescent light exposure. J Invest Dermatol 69: $510-512$

Rick K, Sroka R, Stepp H, Kriegmair M, Huber RM, Jacob K, Baumgartner R (1997) Pharmacokinetics of 5-aminolevulinic acid-induced protoporphyrin IX in skin and blood. J Photochem Photobiol B 40: 313-319

Roberts DJH, Cairnduff F (1995) Photodynamic therapy of primary skin cancer: a review. Br J Plast Surg 48: 360-370

Rud E, Gederaas O, Hogset A, Berg K (2000) 5-aminolevulinic acid, but not 5 -aminolevulinic acid esters, is transported into adenocarcinoma cells by system BETA transporters. Photochem Photobiol 71: 640-647

UKCCCR (1998) United Kingdom Co-ordinating Committee on Cancer Research (UKCCCR) Guidelines for the Welfare of Animals in Experimental Neoplasia (Second Edition). Br J Cancer 77: 1-10

Uehlinger P, Zellweger M, Wagnieres G, Juillerat-Jeanneret L, van Den BH, Lange N (2000) 5-Aminolevulinic acid and its derivatives: physical chemical properties and protoporphyrin IX formation in cultured cells. J Photochem Photobiol B 54: $72-80$

van den Akker JT, de Bruijn HS, Beijersbergen van Henegouwen GM, Star WM, Sterenborg HJ (2000) Protoporphyrin IX fluorescence kinetics and localization after topical application of ALA pentyl ester and ALA on hairless mouse skin with UVB-induced early skin cancer. Photochem Photobiol 72: $399-406$

van den Boogert J, van Hillegersberg R, de Rooij FW, de Bruin RW, Edixhoven-Bosdijk A, Houtsmuller AB, Siersema PD, Wilson JH, Tilanus HW (1998) 5-Aminolaevulinic acid-induced protoporphyrin IX accumulation in tissues: pharmacokinetics after oral or intravenous administration. $J$ Photochem Photobiol B 44: 29-38

Washbrook R, Riley PA (1997) Comparison of delta-aminolaevulinic acid and its methyl ester as an inducer of porphyrin synthesis in cultured cells. Br J Cancer 75: 1417 - 1420 